\title{
Satanism as Reflected in Alan Walker's Selected Song Lyrics
}

\author{
Ina Insani \\ English Literature Departement \\ Universitas Ahmad Dahlan \\ Yogyakarta \\ Tri Rina Budiwati \\ English Literature Departement \\ Universitas Ahmad Dahlan \\ Yogyakarta \\ tri.rina.budiwati@gmail.com
}

Citation: Insani, I. \& Budiwati, T. R. (2021). Satanism as reflected in Alan Walker's selected song lyrics. Notion: Journal of Linguistics, Literature, and Culture, Vol 3(1), p. 53-64. http://doi.org/notion.v3i1.3789

\begin{tabular}{|c|c|}
\hline Article Info & ABSTRACT \\
\hline $\begin{array}{l}\text { Article History } \\
\text { - Article Received } \\
07^{\text {th }} \text { March } 2021 \\
\text { - Article Accepted } \\
27^{\text {th }} \text { April } 2021 \\
\text { Keywords } \\
\text { CDA } \\
\text { Satanism } \\
\text { Song Lyrics } \\
\text { Structure }\end{array}$ & $\begin{array}{l}\text { This research aims to identify and describe the discourse structures and analyze the } \\
\text { representation of Satanism found in the lyrics of the selected songs of Alan Walker. } \\
\text { The researcher used the Critical Discourse Analysis approach by Teun van Dijk to } \\
\text { determine Satanism in these songs. Three elements are used in this analysis, namely } \\
\text { the discourse structure, social cognition, and social context. This research found that } \\
\text { there are elements of discourse structure, whether explaining the micro-structure, } \\
\text { superstructure, or macro-structure, always address Satanism's idea. The social } \\
\text { cognition aspect found that the social condition influences Satanism's notion in the } \\
\text { Alan Walker songs in Norway, where Alan Walker lives open to Satanism. It can be } \\
\text { seen from the analysis of model and memory. The analysis of model in Alan Walker's } \\
\text { song can be influenced by the social conditions around him. The analysis of memory } \\
\text { shows how his personal experience affects the songs he produces. The last aspect in } \\
\text { this research is the social context which analyse the power and access to know the } \\
\text { idea of Satanism in the songs. The analysis of power found that Satanism has a } \\
\text { strong dominance in Norway, as seen from several works such as books, films, and } \\
\text { music with the theme of Satanism. Then, the analysis of access found that the satanic } \\
\text { people managed to control several media in Norway. }\end{array}$ \\
\hline
\end{tabular}




\section{INTRODUCTION}

Recently, critical discourse analysis has an important theoretical perspective in the study of the social setting. For more than two decades, linguists like Van Dijk, Sara Mills, and Fairclough have introduced critical discourse analysis studies. Moreover, the field of critical discourse analysis has a higher level of discourse analysis[1]. It is not only to see the discourse from the grammatical or syntactic but also to see the discourse as the social practice. Van Dijk sees the social cognition factor as an essential element of discourse production[5].

This research focuses on Van Dijk's theory because the object's context in this research is influenced by the social life that correlates with Van Dijk's characteristic of critical discourse analysis. There are three dimensions of the critical discourse analysis model by Van Dijk. The first is discourse structure, which analyses discourse from linguistic use. The second is social cognition, which is focused on how the text is produced. This dimension is Van Dijk's model's point because it shows the text's hidden meaning so that the purpose of creating it is known[18]. The last is the social context, which analyses how the discourse could be accepted by social life[5][19].

In this research, the researcher uses five selected songs by Alan Walker as the primary data to analyze Satanism's idea in those songs. The songs that would be analyzed are "Alone," "Darkside," "Lily," "Faded," and "Lost Control." This research's theory is a critical discourse analysis by Teun Van Dijk using three elements: text analysis, macrostructure, superstructure, microstructure, social cognition, and social context. The two combinations between the selected songs and the approaches are exciting. Using this critical discourse analysis, the researcher could find the Satanism in the song lyric's language structure.

Satanism is one of the forms of worship to the devil which is performed by a group of people though vavrius media such as music[4][6][7][11]. The feature of Satan is part of a pervasive cultural icons group in the popular culture of the late modern West. As quoted from Hjelm, Bogdan, \& Petersen[10], although religious and political extremist dominates the news today, the occasional reference to 'satanic' activities still pops up from time to time in national and international media. The phenomena of Satanism are spreading rapidly especially in the western countries[8][9][15]. One of the countries in England which is famous for spreading Satanism through songs is Norway. As quoted by Partridge and Chrisatianson in Dyrendal[4] that the few products of popular culture seem to connote strongly with Satanism as heavy Norwegian black metal. It has been more closely associated with Satanism than any other subgenre. More than anything else the image of Norwegian "Satanic" revolves around the willingness among a few of band there.

The reason why the researcher is interested to do this research using critical discourse analysis by Teun Van Dijk is because it would find the interpretative deeper meaning from the song lyrics of Alan Walker and to understand the representation of Satanism in the five song lyrics of Alan Walker. Discourse analysis could provide an approach that hopefully gives an understanding of the study of language and ideology. The discourse analysis is applied in this research to explore the role of language use in the development of Satanism issues in the mass media. The most important is to give an understanding of Satanism in the selected songs of Alan walker to the listener and public so that they could select which songs that are suitable for their beliefs.

This framework will explain the theory of discourse structure, social cognition and social context by Teun van Dijk which are taken from[5].

\section{Macro Structure}

Macro structure is a study to analyze the theme and it is called as thematic element. It is to find a global meaning from the text that can be understood by understanding the topic of the text. 


\section{Superstructure}

Superstructure in a model to analyze the structure and how the element of the text is combined becomes one text. This element is named schematic element. The combination of the structure of the text has a plot or scheme from the beginning to the last text.

\section{Microstructure}

Micro structure observes the meaning of the discourse that can be analyzed from the words, sentences, preposition, and other. The things that will be observed are semantic, syntax, stylistic and rhetorical[3].

\section{Background}

Background is the study of the relation between sentences, preposition that can develop certain meaning in a text. Background becomes the acceptable idea in the text. The background contains the supporting idea of the text so that the researcher could dismantle the intent of the text by analyzing the background.

\section{Detail}

The control of the information in the text comes from the detail. How the communicator makes some images in the discourse is based on the detail that he makes. Detail that gives bad image to some communicator will be hidden.

\section{Intent}

Intent is almost the same as the detail. The information that brings a good image for the communicator will be described as long as he can. The purpose of this element is that the public are only presented the information which makes them trust to what the author write. The element of intent shows how the use of language implicitly and hidden in the context of media.

\section{Presupposition}

Presupposition is a statement to support the meaning of the text. Presupposition is an attempt to support an opinion by providing credible assumptions that can be trusted.

\section{Coherence}

Coherence is the study among words or sentences in the discourse. For example, two sentences that describe different fact can be combined and find the coherence of the text. So that the unrelated facts could be connected when the writer uses the right coherence. Coherence could be found in the use of conjunction when he relates fact.

\section{Sentence form}

Sentence form is a syntactical model that can be used to analyze how the text makes sense and can be understood by the social life. Sentence form relate to the way of the author's logical thinking. Sentence form is not only grammatically itself, but also the determination of the meaning based on the sentence structure.

\section{Pronoun}

Pronoun is used to manipulate a language by making an imaginative group. Pronoun is also the tool of the communicator to show his position in the discourse. When the writer expresses their assumption, they might use pronouns "I" or "we". However, when the writer uses "we" rather than "I", it shows that the assumption is a representation of a certain group.

\section{Lexicon}

This element is used to analyze how the communicator chooses certain vocabulary from all the vocabulary that can be used. The choice of vocabulary shows a certain ideology. The same event could be described with different choices of word. Lexicon use to show the fact that would be shared.

\section{Metaphor}

The communicator in sending the discourse not only comes from the message but also from the idiom, utterance, metaphor that can make the discourse more powerful. It also can be used to analyze the meaning of the text. There are three aspects of metaphor analysis, namely vehicle, tenor, and ground. Vehicle is the word which is used for comparison. Tenor is the metaphorical meaning of the word. Then, ground is the basis of the equation of the word.

\section{Social Context}

The third dimension of critical discourse analysis by Van Dijk is social context. Social context is related to how the discourse of certain issues or beliefs develops in society. According to Eriyanto[5], the research was conducted by analyzing how a country produced a discourse that raised certain issues or 
beliefs through books, schools, political speeches, and others. There are two things that need to be considered in analyzing social context. The first is the practice of power, which shows how a group controls other groups or members. This power is based on ownership such as money, status, and knowledge. The second is access, which shows how access between each group to the community. Each person has different access to shared beliefs in the discourses[5].

\section{Social cognition}

Social cognition is the way to understand how the text is produced by analyzing the mental awareness of the writer. According to Van Dijk [20] to find out how an event could be understood, it needs scheme or model and memory. The model is closely related to social representation, how the writer lives between views, beliefs, and prejudices. The other side, memory is the type of belief that is embedded in the mind of someone who form a model.

\section{METHODOLOGY}

The method of research is used to know how to do the research and to solve the problems in research. This research is categorized into qualitative research because it analyses the phenomena of the social and human problem[2]. This research analyses the discourse that contains social phenomena.

The main data of this research are words, vocabularies and sentences that are taken from five selected songs of Alan Walker. The researcher needs another source to support and complete this research, so the writer uses supporting data that are statements and theories related to the research taken from dictionary, journals, books.

This research uses observation method (metode simak) to collect the data by Zaim. The technique of collecting data used in this research is Teknik Telaah Dokumen or documentation technique. As quoted from Zaim[21] documentation technique is the technique of collecting data by noting the variable that would be analyzed. It can be taken from book, magazine, news, and others. There are some steps that are used by the researcher to collect the data. First, Read the lyrics carefully. Then, Underline the data that contain discourse structure. The last,
Classify the data based on the theory of van Dijk in the form of table.

The method of analyzing data in this research uses identity method (metode padan) by Zaim[21]. The concept of this method is to connect the elements of the language and linguistic effect from outside. These elements relate to the meaning, information, context, speech, and others. This method is appropriate to be used to analyse discourse because it does not only explain the language itself but also interprets more deeply so that the meaning behind the discourse could be discovered.

The intralingual equivalent method is also used to create descriptions of themes that hold across stories and the researchers collect descriptions of events or happenings in the text and then configure them into a story using a plotline. The intralingual equivalent is suitable for the analysis of the discourse (song lyric). From the explanation above, there are two techniques of analyzing text by Zaim[21]. The first is dividing key factors technique (teknik pilab), where in this stage is the selection of data that were obtained. The second is Connecting and Comparing technique (teknik bubung banding), in this stage is a comparison or categorization of data that have been selected, then presented in the form of table[13].

\section{RESULT AND DISCUSSION}

\section{Macro Structure}

The researcher analyzes the topic deeply by looking for subtopics which are the main supporters of the general topic formation of the song. Understanding the subtopics of the 5 Alan Walker songs examined in this study, taking a few sentences in the song which semantically refer to the Satanism. The five selected songs of Alan Walker have general theme about Satanism. Those songs are intended to convey the ideology of Alan Walker which is belief in Satan. Those songs show some subtopics which refer to Satanism. Those five songs are entitled "Darkside", "Llily", "Spectre", "Faded" and "Lost Control".

\section{Superstructure}

Superstructure contains the construction of text which shows the plot of the text. That plot explains how part of the text is constructed and sorted to form 
a unity of meaning. The superstructure shows that the text is coherent each other. Each part of the text is related each other, thus forming a scheme show the plot of the discourse. These parts if arranged schematically contain opening, main and closing. Opening is the beginning of the song, main is the important part or topic of the song and closing is the end of the lyric of the song. The five Alan Walker songs examined in this study have the same and complete schema, where each opening, main and closing shows coherence each other to form Alan Walker's view of Satanism.

\section{Micro Structure}

The last element of the text analysis in this structure is micro structure. Micro structure is a structure which analyzes the smaller unit such as words, sentences, coherence, and others. Micro structure consists of some points including semantic, syntax, and stylistic. Every point in the micro structure also have some elements and those elements would be explained below.

\section{Background}

"Fall into the dark side

We don't need the light

We'll live on the dark side"

("Darkside", Line: 8-10)

The setting that the writer tries to convey in this song is the writer believes that the dark side is bolder than the light side. Seen in a few sentences above it appears that the singer tries to bring listeners to believe in the dark side. The meaning of the dark side in the lyrics literally shows a dark and lightless place like the image of Satan in general, but more than that implicitly the dark side shows the characteristics of Satan that are believed by the worshipers as "The Power of Darkness".

"There's creatures who are hiding in the dark" ("Lily", Lone: 9)

The background that is delivered in the song lyrics above is the same as in the previous song which relate to the dark place. Besides, the background in this song shows something that hides in the dark namely "creatures" as seen in line 9 .

'Deep in the dark I don't need the light There"s a ghost inside me
It all belongs to the other side"

(“Spectre”, Line 9-11)

This song tells about someone's desperation to find a place and belief in something. As in previous songs, this song also has a dark background of place that is inhabited by something in it, seen from several sentences as in lines 9-11.

"You were the shadow to my light"

("Faded", Line: 1)

The setting that the singer conveyed in this song contains a belief in something which is not visible or something that is missing as seen in the 1st line lyrics. Besides, the setting of the place in this song is the same as in the previous songs, which is depicting a dark place.

"So I walk into the dead of night"

("Lost Control", Line: 9)

The background shown on this song is inseparable from "The Power of Darkness" which is believed by satanic people. The 9th line shows the dark background of time which is night, then glanced further clarifies the "Dead of night" in the lyrics as the place where Satan is hiding.

\section{Detail}

\author{
"We are not alone \\ We share no stories \\ Just something in your eyes \\ Don't be afraid \\ The shadows know me" \\ ("Darkside", Line: 1-5)
}

The details presented in this song support the singer's invitation to follow it to the dark side. The sentences in line 1 and 4 are sedative ones to persuade the listener to follow it or believe it. Then, line 5 also shows a detail of a belief of something called "Shadow" which would be understood as what the singer expects. "Shadow in this case refers to something dark. The meaning of shadow would be explained more detail in the element of lexicon.

"There's creatures who are hiding in the dark" ("Lily", Line: 9)

The details presented in this song show the singer's belief in Satanism. Again the singer uses sentences and words that identify the characteristics 
of Satanism, such as the use of the words "creature" and "dark".

$$
\begin{aligned}
& \text { "Is this place that I call home" } \\
& \text { ("Spectre", Line: 5) }
\end{aligned}
$$

This song shows details that convince the reader that what the singer expresses is a form of his belief. As in the lyric line-5, the use of the word "home" implicitly shows a comfort of a place like a home for a singer.

"The monsters running wild inside of me" ("Faded", Line: 20)

It shows that the singer felt the presence of "monsters" in his dreams. Satanic people also believe that dreams can be used as a means to meet Satan, because dreams are related to realism of darkness

"Shadow they like my wall"

("Lost Control", Line: 6)

The details displayed on this song also connect with the background of this song. The word "shadow" in the sentence above shows the details related to darkness and monsters.

3. Presupposition

"Let's just believe their lies"

("Darkside", Line: 24)

The line 24 as an explanation to believe the dark side. The paradox of the song's lyrics is also conveyed by Kirban (1980: 15) who explains about the concept of Satanism that "He (Evil) is so deludes those who follow him that they (satanic people) will not believe truth, but rather to choose believe a lie... "

"Follow everywhere I go

Top over the mountain or valley low"

("Lily", Line: 12-13)

The presuppositions displayed in the song lyrics above are assumptions about the strength of Satan. As explained in Chapter 2, Satanic people believe that Satan control all the places, Satan's power is vast and have power like God. The lyric line 12-13 show a presumption that Satan could be found anywhere, whether in the mountain or in a valley.

"Tired of being afraid

But lately, I've lost my faith"

("Lost Control", Line: 19-20)
The presupposition displayed in the two sentences above is almost like a paradox, where the singer is afraid and ends up losing his faith. The sentence above seems to indicate that the singer looks for another belief that makes him more courageous.

\section{Lexicon}

"The shadow know me"
"Take me through the night
Fall into the dark side
We don't need the light"
("Darkside", Line: 6-9)

Every choice of words used in this song always refers to the general theme of the song "Dark Side". The word "shadow" was chosen to display the figure of Satan that is believed by satanic people. Then the words "night" and the phrase "don't need the light" are words and sentences that refer to the word "dark side". When night has arrived they don't need lights, so they fall into the dark side.

"they warned her, don't go there

There's creature who are hiding in the dark"

("Lily", Line: 8-9)

The use of the word "warned" in sentence 8 shows an emphasis that the little girl really should not go to the dark place which is designated in the song.

$$
\begin{aligned}
& \text { "Another start } \\
& \text { You fade away" } \\
& \text { ("Faded", Line: 3-4) }
\end{aligned}
$$

The selection of the word "shadow" which is also found in other Alan Walker songs refers to a certain figure that he admired so much.

$$
\begin{aligned}
& \text { "Shadow they like my wall" } \\
& \text { ("Lost Control", Line: 6) }
\end{aligned}
$$

The 6th sentence, found a choice of related words and shows the characteristics of Satan. The word "Shadow" is interpreted as a figure of Satan.

5. Metaphor

"Beneath the sky

As black as diamonds"

("Darkside", Line: 19-20)

The lyric of the line 20 show the two words which is associated with the equation. The word is a simile which is used to connect two things which are 


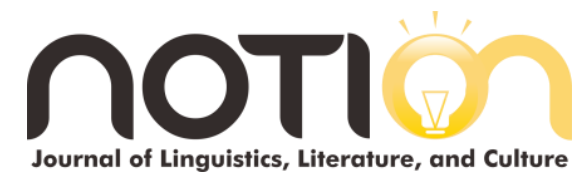

equated by using the word "As" but literally have contradictory meaning. The word which is found in the lyrics line-20 "As black as diamond" is a sentence of comparison between "black" and "diamond". In the scene, the singer has a purpose to describe a dark side as a shiny and very attractive place like "diamond".

\section{"Hello, hello}

Nice to meet you, voice inside my head" (“Spectre”, Line: 13-24)

The line 14 there are also two words that are analyzed metaphorically. The two words are "voice" and "inside". Voice is a comparative word or the vehicle. While from the analysis of the tenor means the sound which is made by someone or something that can be heard. The basic equation of the word shows that the singer heard a word or whispered. Then the word "inside" means something that inside a person. So metaphorically, the two words above show that the singer gets a whisper within him, it could be a memory or a belief. If these meaning are connected, it means that the singer believes in Satanism

"You were the shadow to my light"

("Faded", Line: 1)

The word "shadow" which is a vehicle, then metaphorically it means a place that is dark because the light is covered by something. So the basic equation or ground in the word shows a dark creature because the "shadow" in the word above put as a subject.

\section{Sentence form}

"The shadows know me

Let's leave the world behind"

("Darkside", Line: 5-6)

The sentence form in this song uses the active sentence. The active sentence shows that the subject in the sentence takes precedence and shows the glorification of the object. As in the sentence "The shadows know me" in the line- 5 shows that the singer wants to accentuate the word "shadows" in the sentence. Then on line 6 there is also an imperative sentence that seems to invite the listener to go to the "world" that the singer describes.
"Lily was a little girl

Afraid of the big, wide world"

("Lily", Line: 1-2)

The sentence form that is used in this song is active sentence, generally. The use of active sentence shows that the subject of the sentence would be delivered as the main point or main focus. For example, the lyric line-1 makes Lily as the main character of the song.

"Can you hear me, as I scream your name"

Do you need me, before I fade away"

("Spectre", Line: 2 and 4)

This song uses active sentences generally. Besides, the researcher also found some interrogative sentences as seen in the lyric line- 2 and line- 4 . The analysis of those two sentences shows that the singer is looking for the answer or the information from the object "You".

"The monsters running wild inside of me"

("Faded", Line: 20)

This song uses active sentences generally. For example, in the lyric line-20 the word "Monster" is located as a main subject, which means that the singer wants the hearer more focus on the subject rather than the object.

\section{"Why do I so Small?" \\ ("Lost Control", Line: 7)}

The sentence form on this song uses the active sentence and one interrogative sentence. The interrogative sentence on the 7 th line makes the object "I" as the main point. The sentence does not require an answer, but rather shows disappointment about why the singer is so "small". The word "small" in this sentence does not mean small in literal meaning, but implicitly means powerless.

7. Coherent

"I see I, let's feel it

While we're still young and fearless"

("Darkside", Line: 11-12)

The coherence of a sentence is usually found in several conjunctions. There is only one conjunction found in this song, that is "while" in the line 12. "While" is a conjunction that is a synonym for "when". The conjunction shows time information so 
that it coincides the previous sentence when the subject "I" sees the object "it".

\section{"Now and then she tried to run}

And the on the night with the setting sun"

("Lily", Line: 4-5)

The sentences above show the same coherence. Those use the conjunction "and" to connect two sentences. "And" is part of coordinating conjunctions and functions to connect two equal sentences. The lines 4 and 5 connect two information about what the subject "she" is doing now (in sentence 4) and at night (in sentence 5).

\section{"So I walk into the dead of night \\ Where my monsters like to hide" \\ (“Lost Control”, Line: 9-10)}

The line 9 serves to address the cause and effect of two different sentences. The sentence displays the subject "I" who feels powerless by using the word "small" so he goes to a dark place to find answers to these questions. The line 10 which is a continuation of the previous sentence shows the conjunction "where" which makes it clear that the darkness is a place where "monsters" hide.

\section{Pronoun}

"We're not alone

We share no stories"

("Darkside", Line: 1-2)

There are two pronouns that are found in this song, those are "We" and "I". as quoted from Eriyanto (253) there is a different meaning and purpose in every pronoun which is used in the text. as seen in the lyric line- 1 and line-2, the use of pronoun "We" means that there is a group of people behind this song.

"She grew up within her castle walls

Now and then she tried to run"

("Lily", Line: 3-4)

The uses of pronoun "She" as seen in the lyric line-3 refers to the little girl who is the main character of the song.

"It all belongs to the other side

We live, we love, we lie"

("Spectre", Line: 11-12)
The line 11 also found pronoun "it" which is usually used to refer an objects. However, the use of pronoun "it" that sentence refers to the "ghost" which is mentioned in the previous sentence. Then on line 12 also found the pronoun "we" which means that there is more than one person who lives, loves and lies. The use of pronoun in the sentence above is a bit confusing because it always changes with each new sentence. However, if examined more deeply the pronouns show that the faith of "I" which believes in "ghost" is also believed by some other people.

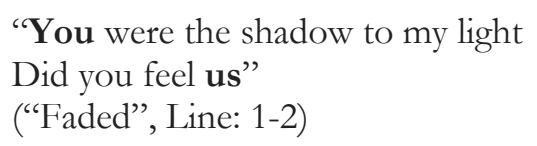

Pronoun "You" refer to someone or something that the singer believed, Then the pronoun "Us" refers to group of people because that pronoun refers to more than one person. That group of people in the context of this research refer to satanic people because the sentence before shows a "Shadow" that is believed by the object "Us".

\section{'You're watching me but I'm bellow when I get caught I hope this is kinda like how they will take me home" \\ ("Lost Contro", Line: 22-25)}

Every sentence in the song lyrics above has a different pronoun. In line 22, the pronoun "You" is displayed as the subject of the sentence. That pronoun is displayed as if it has the power to see the object "me". Then in the line 23 , the pronoun "I" is displayed by showing someone who expects something. In addition, in the line 24 found a pronoun "they" that refer to more than one person. That pronoun is an answer to the expectation of the pronoun "I" which expects comfort place like a home.

\section{The Representation of Satanism in Alan Walker Selected Songs}

1. Social Cognition

The analysis of social cognition related to how the mental representation of the writer in producing his text. Researching the mental representation becomes an important point of the critical discourse analysis model by Van Dijk. As quoted from Eriyanto[5] to find out the social cognition in discourse, there are 
two things that need to be understood as the basis of research, namely model and memory. The models and memories shape Alan Walker's mental representation in producing his songs.

The model influences how meaning in the discourse could be understood. The model in social cognition by Van Dijk is also called a scheme. The scheme is conceptualized as a mental structure that includes views, beliefs and prejudices that develop in society. It could be seen how 5 Alan Walker's songs are influenced by people's views of Satanism.

Satanism is growing rapidly in several countries that embrace liberalism[12] one of which is Norway where Alan Walker lives. Norway is one of the most influential Satanism countries. The fact that Satanism is one of the ideologies that exist in Norway until now is certainly influenced by the people in Norway.

From this fact the model or scheme of the songs created by Alan Walker is influenced by the social conditions of people in Norway who embrace much understanding of Satanism. This fact also reinforces the findings of this study that 5 Alan Walker songs represent Satanism not only from the structure of the language but also Alan Walker's mental representation which is influenced by the social conditions of the communities in which he lives.

As mentioned before that long term memory is about everyday life experience, where his life experience is also influenced by the surrounding environment. Those mental experiences and one's thoughts are influenced by sociocultural knowledge. As Van Dijk[20] said that "people not only have personal beliefs about personal experiences, but also share more general beliefs with others ..." Sociocultural knowledge plays a role in shaping someone's belief in what is believed.

Facts about Satanism[12][16] that developed in Norway where Alan Walker lives as mentioned in the model above also influences how the long term memory that Alan Walker has. Although Alan Walker was not born in Norway, but he grew up in Norway since 1999 and is still there until today. From this we could see how Alan Walker described Satanism in his 5 songs as a form of social shared on his social knowledge. It also shows how he thinks about Satanism that could be accepted for others.

\section{Social Context}

Social context or social analysis is the process of analyzing a discourse by examining how a discourse about a matter is instructed and produced by the community. For that, in this research it is necessary to know how discourse regarding Satanism is produced and accepted by the public.

The important point of social context analysis by Van Dijk is how an understanding could be shared and accepted by all levels of society. There are two ways to analyze the context of each discourse, namely power and access[5].

The purpose of power according to Van Dijk in this case is an ownership of something that is valuable in the view of society such as money, status and knowledge[5]. For this reason, the point of this research is how an understanding could dominate a society.

Satanism has a strong dominance over his ideology in Norway, where Alan Walker lives. This understanding no longer became negative after the religious movements of the 1960s. As quoted from Dyrendal[14], these movements have been quite visible in the public sphere, and although their reception in the countries of the region has varied, individual "experts" hailing from a charismatic background have been important in constructing the public image of Satanism. The power of Satanism has a great influence on society. There are songs, films, and books that have the image of Satanism show that this ideology has great power. This shows that Satanism has a big power to spread it beliefs to others.

As explained in the first paragraph, an ideology that has power must have something valuable that is used as a "weapon" to strengthen its ideology. Valuable ownership could come from the member of the group. If we relate this to Alan Walker, it is very interesting that he has something valuable as a very famous music composer. As a song maker and music composer Alan Walker is very easy to spread his ideology into the music he created and how his understanding could be accepted by the public by using interesting language and music. 
Access is related to how a group or a person could control the community with the understanding they have. In addition to power, great access is also owned by Alan Walker where he has been known by people almost all over the world. Alan Walker's first single, entitled "Faded" which also contains the understanding of Satanism known to the public, not only in Norway but also throughout the world, gives great access to Alan Walker to continue to compose songs that contain Satanism. Large access is obtained by satanic people through media. They made the media to spread the understanding of Satanism to the society[17]. This becomes an important point to find out how Alan Walker's social circumstances have a major influence on the representation of Satanism. As quoted from Eriyanto[5] great access not only provides an opportunity to control the wider community but also determines the topic of how Satanism discourse could be accepted by the community.

\section{CONCLUSION}

Critical discourse analysis by Van Dijk is applied in this study to analyze five songs of Alan Walker. Based on the findings, there are three dimensions that are used to find Satanism, those are discourse structure, social cognition and social context.

The analysis of discourse structure which is explained in the macro structure, superstructure and micro structure shows that the main topic of the five song lyrics by Alan Walker generally shows the idea of Satanism. The plot of the song shows a scheme that tries to highlight the discourse about Satanism in the opening, main, and closing. The same as macrostructure, superstructure also show the text that coherent each other. Each part of the text is related each other, thus forming a scheme that can show the main theme of the discourse. The micro structure suggests a discourse on Satanism found at several points such as background, details, intent, presupposition, sentence form, coherence, pronoun, lexicon and metaphor. The essence of these points is the choice of words used by Alan Walker which implicitly refer to Satanism.

The aspect of social cognition shows how the text can be produced which is closely related to Alan
Walker's mental representation about Satanism. There are two things that need to be understood as the base of research, namely model and memory which shape Alan Walker's mental representation in producing his songs. The analysis of model in Alan Walker's song can be influenced by the social conditions around him. This is influenced by the view, belief, and prejudice that develop in the environment. Then, the analysis of memory shows how his personal experience affects the songs he produces. The memory is formed in long term memory which is also influenced by the surrounding environment. From those two analysis based on the history and existence of Satanism in Norway it is found that the notion of Satanism in the Alan Walker songs is influenced by social condition that is open to Satanism.

The last aspect in this research is the social context that relates to how discourse on Satanism is produced in some places and how the discourse is accepted by society. There are two ways which are used to analyze the social context, namely power and access. Power relates to the domination possessed by a particular group. In this study, it was found that Satanism has a strong dominance in Norway, as seen from several works such as books, films, and music with the theme of Satanism. The second is access that is related to how the ideology controls in Norway. In this analysis it was found that the satanic people managed to control several media in Norway. This shows that Satanism has great access in that country.

\section{REFERENCES}

[1] Alo, M. \& Orimogunje, A. (2013). Discourse strategies and ideology in selected radio lead news of osun state broadcasting corporation, Nigeria. 3L: Language, Linguistics, Literature. The Southeast Asian Journal of English Language Studies, vol. 19(2) p. 111-123.

https://ejournal.ukm.my/31/article/view/1227

[2] Creswell, J. W. (2009). Research Design Qualitative, Quantitative, and Research Approach, $3^{\text {rd }}$ eds. London: Sage.

[3] Cruse, D. A. (2000). Meaning in Language: An introduction to semantics and pragmatics. Oxford University Press. 
https://www.academia.edu/34471403/9962661 4 Meaning in Language an Introduction to $S$ emantics and Pragmatics Oxford Textbooks $\mathrm{i}$ n Linguistics pdf

[4] Dyrendal, A. (2009). Satanism and Popular Music. Equinox.

https://www.academia.edu/18078684/Satanism and Popular Music Lure of the Dark Side Equinox 2009

[5] Eriyanto. (2001). Analisis Wacana: Pengantar Analisis Teks Media. Yogyakarta: LKiS.

[6] Fahrezy, E. A. (2018). An Analysis of Figurative Language Used in Lyrics of Alan Walker's Selected Songs: A Formalism Study. Repository UNR AM. http://eprints.unram.ac.id/10582/.

[7] Fang, J., Grunberg, D., Litman, D. \& Wang, Y. (2017). Discourse analysis of lyric and lyric-based clasification of music. ISMIR.

https://www.semanticscholar.org/paper/Disco urse-Analysis-of-Lyric-and-Lyric-Based-of-FangGrunberg/6792cd4e249961fb41e55c3861dbfacc f62a08a7\#paper-header

[8] Geoghegan, K. (2019, August 23). Hail satan?: The satanist battling for religious freedom. $B B C$ News.

https://www.bbc.com/news/entertainmentarts-49392867

[9] Hiers, R. H. (2009). Satan, Demons, and the Kingdom of God. Scottish Journal of Theology, vol. 27(1), 1974, p. 35-47.

https://doi.org/10.1017/S0036930600059032

[10]Hjelm, T., Bogdan, H., Dyrendal, A., \& Petersen, J. A. (2009). Nordic satanism and satanism scares: The dark side of the secular welfare state. Social Compass, vol. 56, no. 4, 2009, p. 515-29. https://journals.sagepub.com/doi/abs/10.1177 $\lcm{0037768609345972}$

[11]Imam, A. F. (2012). Analisis wacana van dijk pada lirik lagu Irgaa Tani (My Heart Will Go On). Journal of Arabic Learning and Teaching, Vol. 1(1), p. 1-8.

https://journal.unnes.ac.id/sju/index.php/laa/a rticle/view/1504/1451
[12]Laycock, J. P. (2020, March 5). What the satanic temple is and why it's opening a debate about religion. The Conversation.

https://theconversation.com/what-the-satanictemple-is-and-why-its-opening-a-debate-aboutreligion-131283

[13]Mahsun. (2014). Metode Penelitian Babasa: Tahap Strategi, Metode, Dan Tekniknya. Jakarta: Raja Granfindo Persada.

[14]Dyrendal, A. (2005, September 12). Media constructions of 'satanism' in Norway (19881997). Skepsis. www.skepsis.no/media-constructions-ofsatanism-in-norway-1988-1997

[15]Meyer, B. (1995). Delivered from the powers of darkness: Confessions of satanic riches in christian Ghana. Africa: Journal of International African Institue, Vol. 65(2), p. 236-255. https://www.researchgate.net/publication/2319 84378 'Delivered from the Powers of Darkn ess' Confessions of Satanic Riches in Christia n Ghana

[16]Moberg, M. (2012). Religion in popular music or popularmusic as religion? a critical review of scholarly writing on the place of religion in metal music and culture. Popular Music and Society, Vol 35(1), p. 113-130.

http://dx.doi.org/10.1080/03007766.2010.5382 $\underline{42}$

[17]Pattillo, A. (2019, November 3). The most satanic bands in the world, ever!. Louder. www.loudersound.com/features/the-mostsatanic-music-to-listen-to-this-devils-night-aschosen-by-djevel

[18]Putri, I. T. \& Triyono, S. (2018). 'We shall overcome' a humanity song by Roger Waters: critical discourse analysis. Jurnal Humaniora, Vol. 30(2), p. 119-127.

https://jurnal.ugm.ac.id/jurnalhumaniora/article/view/32775

[19]Putri, A. G., Amalia, R. M., \& Pamungkas, K. (2017). Positive Representation of Women in Beyonce's Song Lyrics: A Discourse Analysis. 
National Conference on Teachers' Professional Conference, Vol 1, p. 87-95.

http://tpd.unsyiah.ac.id/publication/index.php/ TPD/article/view/12

[20]van Dijk, T. A. (2011). Ideology and Discourse A Multidisciplinary Introduction. London: SAGE Publication Ltd.

http://www.discourses.org/UnpublishedArticles $\angle$ Ideology $\% 20$ and $\% 20$ discourse.pdf

[21]Zaim, M. (2014). Metode Penelitian Bahasa: Pendekatan Struktural. Padang: UNP Press Padang. http://repository.unp.ac.id/1830/1/Buku\%20M etode $\% 20$ apenelitian $\% 20$ Bahasa.pdf 